İş ve İnsan Dergisi I The Journal of Human and Work

Y1l | Year: Nisan | April 2017

Cilt-Sayı | Volume-Issue: 4 (1)

ss | pp: $1-16$

doi: 10.18394/iid.285653

e-ISSN 2148-967X

http://dergipark.gov.tr/iid/

Araştırma Makalesi

\title{
Strateji Tipolojilerinin Firmaların Kurumsal Girişimcilik Davranışları ile Finansal Performansı Üzerine Etkisi: Türk Sanayi Firmalarında Görgül Bir Araştırma
}

\author{
The Impact of Strategy Typologies on Corporate Entrepreneurship Behavior and \\ Financial Performance of Firms: An Empirical Research in Turkish Industry Firms
}

\author{
Metin Ocak*, a, Gökhan Peker ${ }^{\mathrm{b}}$, Aslan Onur Nacak ${ }^{\mathrm{c}}$
}

\section{MAKALE BİLGİSI}

\section{Anahtar Kelimeler:}

Strateji tipleri, Kurumsal girişimcilik, Finansal performans, Imalat sanayii firmalarl,Hiyerarşik regresyon analizi

\section{Tarihler :}

Geliş 13 Ocak 2017

Düzeltme geliș 13 Mart 2017

Kabul 16 Mart 2017

\section{ÖZ}

Bu çalışma, örgütlerin stratejileri ve kurumsal girișimcilik davranışları arasındaki ilișsiyi ve her ikisinin örgüt performansı üzerindeki etkilerinin ortaya çıkarılması amacıyla yürütülmüş̧ür. Bu maksatla Türkiye'de faaliyet gösteren bazı imalat sanayi firmalarından çeşitli kademelerde çalışan 121 yöneticiden anket tekniği ile toplanan veriler hiyerarşik regresyon analizine tabi tutulmusstur. Yapılan hiverarssik regresyon analizi neticesinde elde edilen bulgular incelendiğinde, örgütlerin strateji tiplerinin örgütlerin kurumsal girişimcilik davranışları ile finansal performansı üzerinde etkileri olduğu görülmüsstür. Ayrıca, kurumsal girișimcilik davranışlarının örgütlerin finansal performans değişkenini yordadı̆̆ ortaya konulmuştur. Bu kapsamda kuramsal gerekçeler ıșı̆̆ında ortaya konulan ilișkiler genel olarak desteklenmiștir. Araştırmada elde edilen tüm sonuçlar alan yazını bulguları ışı̆̆ında tartışılmıştır.

\section{A RTICLE INFO}

\section{Keywords:}

Strategy types, Corporate entrepreneurship, Financial performance, Manufacturing industry firms, Hierarchical regression analysis

\section{Article history:}

Received 13 January 2017

Received in revised form 13

March 2017

Accepted 16 March 2017

\begin{abstract}
A B S T R AC T
This study was conducted in order to determine the relationship between organizational strategies and corporate entrepreneurial behaviors and the effects of both on organizational performance. For this purpose, a hierarchical regression analysis was executed on the data collected from 121 managers who work in some manufacturing industry firms operating in Turkey. Results of the hierarchical regression analysis showed that organizations' strategy types have effects on corporate entrepreneurship behaviors and financial performance. In addition to this, it was found that corporate entrepreneurship behaviors had significant effects on financial performance. In this context, the relations revealed in the light of theoretical background are generally supported. All these results were discussed in the light of the findings in the literature.
\end{abstract}

\footnotetext{
", a Iletişim Kurulacak Yazar, Kara Kuvvetleri Komutanlığı, Gelibolu Ordu Evi, Çanakkale, Türkiye. metinocak@hotmail.com

${ }^{b}$ Kara Kuvvetleri Komutanlığl, Ankara, Türkiye.

${ }^{c}$ Adil Işılk Group, İstanbul, Türkiye.
} 


\section{GíRiş}

Kurumsal girişimcilik; örgütlerin yaşamlarını devam ettirmeleri, sürdürülebilir rekabet üstünlüğü sağlamaları, üst düzey performansa ulaşmaları maksadıyla yürütülen yenilikçilik, stratejik yenilenme ve yeni iş girişimi başlatma davranışlarının toplamını ifade etmektedir. $\mathrm{Bu}$ bağlamda kurumsal girişimcilik örgütler için son derece kritik bir süreçtir ve bugüne kadar girişimcilik, stratejik yönetim ve ekonomi yazınında merkezi bir konu olarak ele alınmıştır (Dess, Lumpkin \& Jeffrey, 1999).

Kurumsal girişimcilik ile benzer şekilde örgüt stratejisi rakiplerin faaliyetlerini göz önünde bulundurarak, işletmenin yaşamını sürdürebilmek, sürdürülebilir rekabet avantajı yaratmak ve ortalamanın üzerinde getiri elde edebilmek adına belirlenmiş, nihai sonuç odaklı, uzun dönemli, dinamik kararlar topluluğu olarak tanımlanmaktadır (Ülgen \& Mirze, 2004). Her iki tanımdan görüleceği üzere kurumsal girişimcilik ve örgüt stratejisinin temel bağımlı değişkenini örgüt performansı oluşturmaktadır.

Kurumsal girişimcilik ve örgüt stratejisi arasındaki ilişkiye yönelik farklı görüşler bulunmaktadır. Bazı çalışmalarda (Antoncic, 2006; Moreno \& Casillas, 2008; Peltola, 2012; Hornsby, Kuratko, Holt \& Wales, 2013; Crawford \& Kreiser, 2015) kurumsal girişimcilik örgütlerin bir stratejisi olarak ele alınırken bazı çalışmalarda (Hornsby, Kuratko \& Zahra, 2002; Ireland, Covin \& Kuratko, 2009; Özdemirci, 2011) örgüt stratejisinin örgütlerin kurumsal girişimcilik sürecinin gerçekleştirilmesi için temel oluşturduğu ifade edilmektedir. Bu kapsamda bazı yazarlar (Zahra, Randersonk \& Fayolle, 2013; Kuratko, Hornsby \& Hayton, 2015) kurumsal girişimcilik alanında günümüzdeki en önemli tartışmanın strateji ve kurumsal girişimcilik etkileşimi üzerinde yoğunlaştığını ifade etmekte ve aralarındaki bağlantıyı ortaya çıkarmanın önemine vurgu yapmaktadırlar.

$\mathrm{Bu}$ bağlamda araştırmanın amacı örgütlerin stratejileri ve kurumsal girişimcilik davranışları arasındaki ilişkinin ve her ikisinin örgüt performansı üzerindeki etkilerinin ortaya çıkarılması maksadıyla Türkiye'de faaliyet gösteren imalat sanayi firmalarından elde edilen verilerin test edilmesidir. $\mathrm{Bu}$ amaca yönelik olarak içerikte öncelikle kurumsal girişimcilik ve strateji arasındaki farklılıklar ve ortak yönler birleştirici bir yaklaşımla ele alınacak ve örgüt performansına etkileri tartışılacaktır. Müteakiben söz konusu imalat sanayi firmalarından elde edilen verilerle stratejinin kurumsal girişimcilik ve her ikisinin örgüt performansı üzerindeki etkisi test edilecektir. Böylece kurumsal girişimcilik ve strateji ilişkisine yönelik kuramsal katkılar sağlanması, ayrıca araştırma değişkenleri arasındaki etkileşimlerin ortaya konulması ile Türkiye'de faaliyet gösteren imalat sanayi firmalarına yönelik öneriler getirilmesi hedeflenmektedir.

\section{KAVRAMSAL ÇERÇEVE}

Geliştirilecek hipotezlere kuramsal gerekçe oluşturmak amacıyla çalışmada ele alınan kurumsal girişimcilik, örgüt stratejisi ve örgüt performans1 konuları aşağıda tartışılmıştır.

\subsection{Kurumsal Girişimcilik}

Son 40 y1lda gelişen kurumsal girişimcilik; örgütsel ve ekonomik gelişmenin, performans ve zenginlik yaratmanın önemli bir ögesi olarak kabul edilmektedir (Kuratko, vd., 2015). Başlangıçta bireysel girişimci için birçok firsatların olduğu ekonomik düzen son yıllarda güçlü kurulu örgütlerin varlığ ittifaklar oluşturduğu pazarlara küçük oyuncuların giremediği bir düzene dönüşmüştür. Kurumsal girişimcilik örgütlerde belli bir elit girişimci gruptan ziyade tüm personelin günlük faaliyetlerinin bir parçası olarak görülmektedir (Theresa, Chan, Susan, Tai \& David, 2010). Bu bağlamda kurumsal girişimcilik örgüt düzeyinde resmi veya gayri resmi olarak yeni iş fırsatlarının takip edilmesi ve keşfedilmesi için stratejik yenilenme, yenilikçilik ile yeni iş girişimi başlatma gayretlerinin toplamını ifade etmektedir (Morris, Kuratko \& Jeffrey, 2011; Bierwerth, Schwens, Isidor \& Kabst, 2015).

Zahra ve Garvis (2000) yenilikçiliği, bir örgütün yeni ürün yaratması, başarılı bir şekilde pazara sunması veya örgütsel yenilikleri ile ilgili taahhüdü olarak ifade etmektedirler. Bloodgood, Hornsby, Burkemper ve Sarooghi (2015) ise yenilikçiliğin yeni bir ürün ve hizmet olabileceği gibi yönetsel bir sistem, yeni bir plan veya programda olabileceğini belirtmektedirler. Yeni iş girişimi başlatma boyutu özerk veya yarı özerk varlıklar, bölüm ve örgütlerin oluşturulması üzerine yoğunlaşmaktadır (Zehir \& Eren, 2007). Bazen örgütler gerekli kaynaklara sahip değil ise bir firsattan yararlanmak ve kaynaklara erişmek için başka örgütler ile ittifaklar kurabilmektedirler (Sânchez, Criado \& Martinez, 2009). Stratejik yenilenme ise örgütlerin üzerine inşa edildiği fikirlerin tekrar yenilenmesi suretiyle örgütün dönüştürülmesi, stratejilerinin tekrar oluşturulması, yeniden örgütlenme ve örgütsel değişim üzerinde odaklanmaktadır (Zahra, 1993). 
Diğer bir deyişle stratejik yenilenme aralıklı stratejik dönüşüm veya adımsal yenilenmeyi içermektedir (Agarwal \& Helfat, 2009). Bierwerth ve arkadaşları (2015) firmanın düşük maliyet stratejisinden farklılaşma stratejisine geçmesini bir stratejik yenilenme örneği olarak vermektedirler. Söz konusu üç boyut ile ilgili gayretler örgütlerde her seviyede ortaya çıkmakta ve örgütlerin performansına katk1 sağlamaktadır (Guth \& Ginsberg, 1990; Covin \& Slevin, 1991; Antoncic \& Hisrich, 2001; Antoncic \& Hisrich, 2004).

Kurumsal girişimcilik ile ilgili yerli ve yabancı yazında yapılan çalışmalarda birçok öncül değişken üzerinde odaklanılmıştır. (Zahra, 1993; Jauhari, 2005; Zehir \& Eren 2007; Antoncic, 2007; Bulut, Fiş, Aktan, \& Y1lmaz, 2008; Fiş, 2009; Şanal, 2011; Özdemirci, 2011; Karacaoğlu, Bayrakdaroğlu \& San, 2013; Kurtuldu, 2014; Üstün, 2015). Bunlar; çevre, ödüllendirmenin doğru kullanılması, üst yönetim desteği, kaynak mevcudiyeti, destekleyici örgüt yapısı, risk alma, hataya hoşgörü, örgüt büyüklüğü, teknoloji, örgüt amaçları, öğrenen örgüt seviyesi, liderlik vb. değişkenlerdir. Genel olarak bu değişkenler örgütün çevresi ve örgütün iç faktörleri olarak sınıflandırılmaktadır. Örgütlerin iç faktörlerinden birisi de örgütlerin stratejileridir (Özdemirci, 2011). Konuya ilişkin Zahra ve arkadaşları (2013) kurumsal girişimcilik alanında günümüzdeki en önemli tartışmanın strateji ve kurumsal girişimcilik etkileşimi üzerinde yoğunlaştığını ifade etmektedirler. Benzer şekilde Kuratko ve arkadaşları (2015) kurumsal girişimcilik alanında yeni yönelimin strateji ve kurumsal girişimcilik arasındaki bağlantıyı ortaya çıkarmak olduğunu belirtmektedirler.

\subsection{Strateji}

Strateji kelimesi günümüze kadar çeşitli safhalardan geçerek birçok anlamda kullanılmış, ancak anlamsal köklerini kaybetmemiştir (Mainardes, Ferreira \& Raposa, 2014). Strateji, eski Yunan'da "Strategos" yani orduya komuta eden general anlamında kullanılan kelimeden gelmektedir. Strateji aynı zamanda kaynakların etkin kullanımı ile düşmanın yok edilmesi için yapılan bir plan ve savaş sanatı olarak tanımlanmaktadır (Steiner \& Miner, 1977). Strateji kavramı İkinci Dünya Savaşını müteakip iş dünyasında yaşanan hacimsel genişlemeden ve iş örgütlerinin takip edecekleri bir kılavuza ihtiyaç duymalarından dolayı iş dünyasına girmiştir (Bracker, 1980). Strateji terimi birçok alanda kullanılmasından dolayı politika, taktikler, hedefler, amaçlar ve programlar gibi birçok anlama gelebilmektedir. Stratejinin kapsayıc bir tanımının yapılması maksadiyla 2008 yılında yapılan bir çalışmada, 1962-2008 yılları arasında yayımlanan makale ve kitaplarda yer alan 91 strateji tanımı çeşitli tekniklerle incelenerek ortak bir tanıma varılmaya çalışılmıştır. Söz konusu çalışmada stratejinin "Kaynakların rasyonel kullanılmasıyla firmanın performansinı artırmasi ve/veya hedeflerini elde etmesi için gerekli eylemlerinde ihtiyaç duyduğu çevresi ile ilişkilerdeki dinamikler" olarak ifade edilebileceği önerisi yapılmıştır (Ronda-Pupo \& Guerras-Martin, 2010).

Strateji kelimesi stratejik yönetim alanının ana kavramıdır. Stratejinin iş dünyasına girmesiyle gelişen stratejik yönetim, stratejik planlamanın yanı sıra, işletme içi (Yönetim biçimi, yapısı, kültürü ve davranış gibi) unsurları, karar verme yöntemleri, değişim araçları, strateji oluşturma, uygulama ve kontrol gibi işlevleri de ilgi alanına dâhil etmiştir (Altuntaş, 2010). Stratejik yönetimi diğer yönetim bilimlerinden ayıran temel fark, örgütsel performans üzerine araştırmaları konu edinmesidir (Ketchen, Thomas, James \& McDaniel,1996). Bu fark alanda, süreç ve içerik olarak ayrışmaya yol açmıştır (Summer, 1980; Chakravarhy \& Doz, 1992; Herrmann, 2005). Strateji sürecine ilişkin araştırmalar örgütlerin hedeflerine nasıl ulaşacağına ilişkin karar verme ve yönetim sistemleri üzerine odaklanırken, stratejinin içeriğine ilişkin çalışmalar ise örgütlerin faaliyet gösterdiği sektör, firmanın sektörde konumlanması, rekabetçi davranışlar ve örgüt hedeflerine odaklanmaktadır. Süreç ve içerik araştırmaları birbirini tamamlayarak stratejik yönetim alanının temelleşmesine katkı sağlamaktadır (Herrmann, 2005).

Diğer taraftan stratejik yönetim alanında etkili olduğu kabul edilen on okul bulunmaktadır. Bunlardan üçü (Tasarım okulu, planlama okulu ve konumlandırma okulu) strateji sürecini öngörücü bir yaklaşımda bulunurken, sonraki altısı (Girişimcilik okulu, bilişsel okul, öğrenme okulu, güç okulu, kültür okulu, çevre okulu) betimleyici bir nitelik taşımakta, biçimselleşme okulu ise hem öngörücü hem betimleyici bir tarzda ilk dokuzunu bütünleştirici bir çerçeve sunmaktadır (Sarvan, Arıcı, Özen, Özdemir \& İçigen, 2003).

Ayrıca strateji örgütlerin farklı seviyelerinde mevcuttur. Bunlar; yukarıdan aşağıya doğru kurumsal, iş yönetim, işlevsel stratejiler olarak ele alınmaktadır (Ülgen \& Mirze, 2004). Stratejinin oluşturulması hiyerarşik yapının en üst seviyesinden başlamakta ve aşağıya doğru inmektedir. Aşağıya doğru akış ile birlikte stratejinin oluşturulması ve tamamlanması oranları arasında değişim yaşanmaktadır (Dollinger, 2008). Kurumsal stratejiler iş setinin seçimi ve kaynakların bunlara tahsisi, iş stratejileri ise bir endüstride nasıl rekabet edileceği ile ilgilidir (Hofer \& Schendel, 1978). İşlevsel stratejiler ise pazarlama, satış, servis vb. bölümler sorumluluğunda hazırlanan iş yönetim 
stratejilerini destekleyen stratejilerdir (Rodrigues, 2002).

Stratejiyi içerik olarak ele alan ve bir biçimselleșme okulu çalışması olarak kabul gören Miles ve Snow'un (1978) tipolojisi aynı zamanda kurumsal stratejiyi de temsil etmektedir. . Söz konusu tipoloji örgütleri bütüncül bir sistem olarak gören tek tipolojidir ve farklı birçok stratejinin çalışılması konusunda uygun formata sahiptir (Jennings \& Hindle, 2004). Miles ve Snow'un (1978) dört strateji tipi (Savunmac1, öncü, analizci ve tepkici) örgütlerin tümünün stratejik yönelimini karakterize etmektedir (Doğan, 2008). Miles ve Snow (1978) başlangıçta tepkici tipi dört tip ideal strateji tipi arasında saymışıtır, fakat daha sonraları bu strateji tipini artık tip davranış olarak ifade etmiştir (Wang, 2008). Söz konusu tipoloji işletmenin üç problem alanına nasıl yanıt verdiğine dayandırılmaktadır. Bunlar; örgütün ürün pazar alanını ifade eden girişim, odaklanılan üretim ve dağıtım süreci ile kullanılan teknolojiyi ifade eden mühendislik, örgüt yapısının ve politikasının oluşturulması, rasyonelleştirilmesi ve yenilenmesini ifade eden yönetimdir (Isoherranen \& Kess, 2011).

Savunmacı strateji izleyen örgütler sabit ürün ve hizmetlere sahiptirler. Rakipleri ile fiyat, kalite ve hizmet üzerinden rekabet etmektedirler. Girişim problemi ile sabit bir pazar payının nasıl sürdürüleceği konusunda karşılaşmaktadırlar. $\mathrm{Bu}$ yüzden sabit bir çevrede iyi faaliyet göstermektedirler (Akbolat, 2009). Çözüm olarak maliyet liderliği, belirli alanlarda uzmanlaşma, düşük maliyeti sürdürmek için standart teknik süreçleri kullanmayı ve yüksek kaliteyi tercih etmektedirler (Khani \& Ahmadi, 2012). Yönetim problemlerini aşmak için verimliliği sürdürmeye ve bu bağlamda merkezileşme, resmi süreçler ve ayrı fonksiyon alanları üzerinde odaklanmaktadırlar. Çevreleri yavaş değiştiğinden uzun dönemli planlamaya önem vermektedirler. Yeni pazarlara yönelmekten ziyade mevcut pazarı tamamen kapatmaya ve rakipleri mevcut pazara sokmamaya çalışmaktadırlar (Isoherranen \& Kess, 2011).

Öncü stratejiyi uygulayan örgütler pazarda ilk olan veya geniş bir ürün-pazar yelpazesi olan örgütlerdir. Meydana gelebilecek beklenmedik durumlar için daima hazırlıklıdırlar ve rakiplerinin cevap vermesi gereken yenilikleri yapmaktadırlar (Khani \& Ahmadi, 2012). Girişim problemi ile yeni ürün ve pazar firsatlarını bulma ve yararlanma konusunda karşılaşmaktadırlar. Değiş̧en, öngörülemeyen ve başarının yeni firsatların araştırılmasına bağlı olduğu bir iş çevresi içerisinde faaliyet göstermektedirler. Geniş ürün ve hizmet hatlarına sahiptirler ve verimlilikten ziyade yaratıcıllğa odaklanmaktadırlar. Tek bir teknolojiye bağlı değillerdir (Sihvonen, 2010). Yönetim problemleri farklı iş eylemlerini koordine etmek ve yeniliği ortaya çıkarmak şeklinde ortaya çıkmaktadır. Bu problemler yapının yataylaştırılması, kültürlü ve bilgili kişilerin görevlendirilmesi, yönetim kademelerinin azaltılması, bölümler arası koordinasyon ve ortak iş yapma yöntemleri ile çözülmektedir (Isoherranen \& Kess, 2011). Yöneticileri yeni ürünler üretmek, yeni pazarlara girmek gibi yüksek risk almaktan hoşlanmaktadırlar (Doğan, 2008).

Analizciler hem savunmacı hem de öncü stratejilerin özelliklerini taşımakta, sabit ve değişkenlik arasında denge aramaktadırlar. Girişim problemi ile mevcut pazarlarda paylarını nasıl sürdürebilecekleri, yeni pazar ve ürün firsatlarından nasıl yararlanabilecekleri şeklinde karşılaşmaktadırlar (Sihvonen, 2010). Analizci örgütler yeni bir mal veya hizmet piyasasına ilk giren olmamaktadırlar. Dikkatli bir şekilde yeni bir alana giren rakibini incelemekte, sonra mamulün tasarım, üretim ve dağıtımında daha etkili şekilde pazara girmektedirler (Doğan, 2008). Mevcut ürünlerde verimliliği sürdürürken yeni işleri takip etmek için esnek olmaya çalışmaktadırlar. Düşük maliyetler için teknik verimlilik, değişen pazarda rekabet edebilmek için yeni ürün ve hizmetler üzerine odaklanmaktadırlar. Yönetim problemi her iki durumun nasıl yönetileceği ile ilgilidir. Dolayısıyla stratejiyi uygulayanlar bölümler arası ortak iş yapmayı desteklemekte, riski minimize, kâr için firsatları maksimize etmeye çalışmaktadırlar (Isoherranen \& Kess, 2011).

Tepkici örgütlerin sistematik bir stratejileri, işlevsel yap1 ve tutarl eylemleri yoktur (Sihvonen, 2010). Çevrelerinde karşılaşacakları değişimlere karşı hazırlıklı değillerdir. $\mathrm{Bu}$ tür örgütler çevrede kendilerine baskı geldiği zaman cevap vermeye çalışmaktadırlar (Doğan, 2008). Dolayısıyla proaktif bir stratejileri yoktur, değişimlere tepkisel cevap vermektedirler (Isoherranen \& Kess, 2011). Tepkici strateji farklı zaman aralıkları ile ortaya çıktığından ve duruma göre diğer stratejilerinde özelliklerini taşıyabileceğinden gerçek bir strateji sayılmamaktadır (Khani \& Ahmadi, 2012).

\section{3. Örgüt Performansı}

Performans, amaçların gerçekleştirilmesi için gösterilen planlı tüm çabaların ve sonuçların nitel ya da nicel olarak değerlendirilmesidir (Akman, Özkan \& Eriş, 2008). Performans değerleme ise yönetimin kontrol işlevinin en önemli faaliyeti olarak birey ve örgüt düzeyinde ele alınmaktadır. Birey düzeyinde performans değerleme insan kaynakları uygulamaları açısından geri bildirim sağlarken örgüt performansının ölçülmesi örgütlerin 
etkili yönetimi için kritik önem arz etmektedir. Ayrıca örgüt performansı günümüzde müșterileri örgüte cezbeden en önemli göstergedir (Al-Swidi \& Fadzil, 2014).

Geçmiş yıllarda örgüt performansının ölçülmesinde genel olarak; kârlılık, finansal yapı (borç/toplam sermaye oranı), Tobin's Q (piyasa değeri/defter değeri oranı), aktif kârlılık değişimi, özsermaye değişimi, hisse senedi fiyat getirisi, şirketin üretkenliği, nakit akım değişimi, özsermaye kârlılığ1 gibi finansal ölçütlerin kullanıldığı görülmektedir (Meydan \& Basım, 2007).

Günümüzde ise örgütlerde maddi ve fiziksel varlıkların öneminin maddi olmayan ve entelektüel varlıklara doğru kayması nedeniyle örgüt performansının ölçülmesinde sadece finansal göstergelere odaklanılmasına ciddi eleştiriler yapılmaktadır (Erkuş, 2004). Bu nedenle Balanced Scorecard (BSC) (Kaplan \& Norton, 1996) gibi çok boyutlu performans değerleme yöntemleri ortaya çıkmıştır. Ancak ister geleneksel isterse çok boyutlu ölçüm yöntemleri kullanılsın finansal performans tüm varlıkların odak noktasını oluşturmaktadır.

Finansal performans kurumsal girişimcilik alanında yapılan araştırmalarda birçok boyut ile ölçülmüştür. Bu kapsamda Antoncic ve Hisrich (2003) tarafindan büyüme ve kârlılık; Luo, Zhou ve Liu (2005) tarafından satış büyüklüğü ve pazar payı; Aaboen, Lindelöf, Koch ve Löfsten (2006) tarafindan istihdam/satış büyümesi ve kârlılık; Sueyoshi, Goto ve Omi (2010) tarafindan toplam gelir, satılan malların maliyeti, toplam çalışan sayısı ve maddi varlıkların defter değeri olarak ele alınmıştır. Genel olarak bakıldığında kurumsal girişimcilik araştırmalarında çoğunlukla büyüme ve kârlılık boyutlarının kullanıldığı görülmektedir (Lumpkin \& Dess, 1996; Antoncic \& Hisrich, 2003; Rutherfold \& Holt, 2004; Ağca \& Kandemir, 2008; Ocak \& Basım, 2015). Brinckman, Grichnik ve Kapsa da (2010) yaptıkları meta analizinde performans boyutları olarak genellikle kârlılık ve büyümenin kullanıldığını tespit etmişlerdir.

\subsection{Kurumsal Girişimcilik ve Strateji ile Finansal Performans Arasındaki İlişkiler}

Kurumsal girişimcilik ve örgüt stratejisi arasındaki ilişkiye yönelik farklı görüşler bulunmaktadır. Bazı çalışmalarda (Antoncic, 2006; Moreno \& Casillas, 2008; Peltola, 2012; Hornsby vd., 2013; Crawford \& Kreiser, 2015) kurumsal girişimcilik örgütlerin kurumsal bir stratejisi olarak ele alınırken bazı çalışmalarda (Hornsby vd., 2002; Ireland vd., 2009; Özdemirci, 2011) örgüt stratejisinin örgütlerin kurumsal girişimcilik sürecinin gerçekleştirilmesi için temel oluşturduğu ifade edilmektedir. Meyer ve
Heppard (2000) her ikisinin birbirinin tamamlayıcısı olduğunu ifade etmektedir. Ireland, Hitt, Camp ve Sexton (2001) ise strateji ve girişimci eylemlerin bütünleştirilmesinin maksimum ilerleme ve sonuçlar için önemli olduğunu belirtmektedirler. $\mathrm{Bu}$ kapsamda bazı yazarlar (Zahra vd., 2013; Kuratko vd., 2015) kurumsal girişimcilik alanında günümüzdeki en önemli tartışmanın strateji ve kurumsal girişimcilik etkileşimi üzerinde yoğunlaştığını ifade etmekte ve aralarındaki bağlantıyı ortaya çıkarmanın önemine vurgu yapmaktadırlar. Altuntaş (2010) ise girişimcilik ve stratejik yönetim düşüncesinin birleştirilmesine yönelik çalışmaların gerekçesini, iki alanın bağımlı değişkenini, örgütsel performans olgusunun oluşturması ve stratejik yönetim düşüncesinin odak noktasının, girişimcilik olgusuna doğru kaymasına bağlamaktadır.

Ogot (2012) stratejinin başarısının birçok faaliyeti iyi yapmak ve bunları bütünleştirmekten geçtiğini belirtmektedir. Bu bağlamda strateji örgütlerin içsel kaynak yapısı ile çevrenin uyumlaştırılmasını sağlamak maksadıyla verilen kararlar bütününü ifade etmektedir. Kararlar bütünü hem stratejinin oluşturulması hem de tamamlanmasını kapsamaktadır (Dollinger, 2008). Stratejinin oluşturulması planlama ve analiz safhalarını, tamamlanma safhası ise stratejiyi gerçekleştirmek için yapılan eylemlerin yürütülmesi ve değerlendirilmesini kapsamaktadır. $\mathrm{Bu}$ süreç stratejik yönetim olarak adlandırılmaktadır. Stratejik yönetim konseptinin kalbinde ise girişimcilik yer almaktadır (Kraus \& Kauranen, 2009).

Kurumsal girişimcilik ise örgütlerin ortaya çıkan ihtiyaçlarını karşılamak maksadıyla, orijinal çözümler üretilmesi, yeni örgütlerin yaratılması ve stratejik yenilenme eylemlerini ifade etmektedir (Bouchard, 2001). Dolayısıyla kurumsal girişimcilik yenilik odaklı iken stratejik yönetim yapılan işlerin daha iyi yapılması üzerinde durmaktadır. Diğer taraftan girişimcilik sürecinin temelinde birey varken strateji yönetici merkezlidir. Sebora, Theerapatvong ve Lee (2010) yöneticilerin başarılı kurumsal girişimcilik uygulamalarına neden olan faktörleri anlaması ve uzun süreli firma başarısını sağlamak için girişimci ruhu cesaretlendiren yönetim stratejilerine geçiş yapmalarının önemine vurgu yapmaktadırlar.

Martins ve Kato (2010) örgütlerin başarısını iç ögeler (Strateji, yapı, süreç ve ideoloji) ve dış çevrenin uyumuna bağlamaktadırlar. Bu kapsamda girişimcilik kurumsal stratejinin önemli bir elemanıdır (Ireland vd., 2009). Hitt, Ireland, Camp ve Sexton, (2002) girişimciliği strateji perspektifinde icra edilen eylemler olarak tarif 
Tablo 1: Ömekleme Ait Dem ografik Bilgiler

\begin{tabular}{|c|c|c|c|}
\hline $\begin{array}{l}\text { Demografik } \\
\text { Değişken }\end{array}$ & Kategori & Say1 & Yüzde \\
\hline \multirow{3}{*}{$\begin{array}{l}\text { Firm a } \\
\text { Büyüklüğğ }\end{array}$} & Küçük Boy (1-49 personel) & 56 & $\% 46$ \\
\hline & Orta B oy ( $50-249$ personel) & 33 & $\% 27$ \\
\hline & Büyük Boy $\gg 250$ personel) & 32 & $\% 27$ \\
\hline \multirow{4}{*}{ Firm a $Y$ aşı } & $1-10 y^{11}$ & 25 & $\% 21$ \\
\hline & $11-20 \mathrm{y}^{11}$ & 8 & $\% 7$ \\
\hline & $21-30 \mathrm{y}^{11}$ & 64 & $\% 53$ \\
\hline & 31 y11 üzeri & 24 & $\% 20$ \\
\hline \multirow{4}{*}{$\begin{array}{l}\text { Yöneticilerin } \\
\text { Görevi }\end{array}$} & Yönetim Krl. Bş̧//Genel & 48 & $\% 40$ \\
\hline & $\begin{array}{l}\text { Ba̧̧kan Yard/GenelMüdür } \\
\text { Yard.Direktör vb. }\end{array}$ & 40 & $\% 33$ \\
\hline & $\begin{array}{l}\text { İnsan Kaynaklar1/Personeli dari } \\
\text { İ şler Müdürü vb. }\end{array}$ & 17 & $\% 14$ \\
\hline & Diğer Müdür & 16 & $\% 13$ \\
\hline \multirow{2}{*}{ Cinsiyet } & Exkek & 105 & $\% 87$ \\
\hline & Kadin & 16 & $\% 13$ \\
\hline \multirow{4}{*}{$\begin{array}{l}\text { Mevcut } \\
\text { Pozisyonda Görev } \\
\text { Süresi }\end{array}$} & $1-4 \mathrm{y} 1$ & 40 & $\% 33$ \\
\hline & $5-10 \mathrm{y} 11$ & 33 & $\% 27$ \\
\hline & $11-20 y^{1} 1$ & 32 & $\% 27$ \\
\hline & 21 y11 üzeri & 15 & $\% 13$ \\
\hline
\end{tabular}

etmektedirler. Hornsby vd. (2002) işletme stratejisinin örgütlerin kurumsal girişimcilik aktivitelerinin gerçekleştirilmesi için gerekli olan kaynakların sağlanması konusunda temel oluşturduğunu ifade etmektedirler. Dolayısıyla karar verilmiş işletme stratejisi örgütteki girişimci eylemlere önemli bir girdi sağlamaktadır (Zahra, Neubaum \& Morten, 2000).

Literatür Miles ve Snow'un (1978) tipolojisinin örgütlerin girişimci eylemlerini etkilediğini belirtmektedir (Moreno \& Casillas, 2008; Raman, 2015). Bu bağlamda örgütlerin öncü stratejiye odaklanması arttıkça girişimcilik davranışı artmaktadir (Moreno \& Casillas, 2008). Lekmat ve Chelliah (2011) ise yaptıkları çalışmada analizci stratejinin, öncü stratejilere göre kurumsal girişimcilik üzerinde biraz daha fazla etkisi olduğunu, savunmac1 stratejinin kurumsal girişimcilik üzerinde bir etkisi olmadığını belirlemişlerdir. Jennings ve Seaman (1990) yaptıkları çalışmada öncü stratejinin savunmacı stratejiye nazaran daha yüksek seviyede girişimci eylemlere neden olduğunu tespit etmişlerdir. Ayrıca öncü stratejinin yenilikçilik, risk alma ve yeni firsatların takibini sağlarken, savunmacı stratejinin durağanlık ve örgüt içi verimlilik üzerinde odaklandığını belirtmektedirler. Raman (2015) örgütlerin kurumsal girişimcilik davranışlarının savunmac1, öncü, analizci ve tepkici stratejilerden etkilendiğini belirtmektedir. Yapılan bir bibliometrik analizde kurumsal strateji, örgüt yapıs1, kurum kültürü, insan kaynakları yönetimi ve çevre, kurumsal girişimciliğin etkililiği için önemli olarak görülmektedir (Ireland vd., 2009). Dinçer, Yıldırım ve Dil (2012) yaptıkları çalışmada girişimciliğin firma stratejisinden etkilendiğini belirtmektedirler.

Strateji ve örgüt performansına yönelik yapılan bazı çalışmalarda her ikisinin birbiriyle bağlantılı olduğu tespit edilmiştir (Ittner \& Larckner, 1998; Banker, Potter \& Srinivasan, 2000; Kraus \& Kauranen, 2009). Moreno ve Casillas (2008) yaptıkları çalışmada analizci stratejinin performans ile ilişkili olduğunu, savunmacı ve tepkici stratejinin ise çok ilişkili olmadığını tespit etmişlerdir. Khani ve Ahmadi'nin (2012) 62 sanayi işletmesi üzerinde yaptıkları araştırma sonucunda analizci strateji ile çok boyutlu performans ölçüm yöntemlerinden biri olan BSC'nin tüm alt boyutları arasında pozitif bir ilişki tespit edilmiştir. Öncü strateji ile BSC boyutları arasında anlamlı bir ilişki tespit edilmezken, savunmac1 strateji ile BSC boyutları arasında negatif bir ilişki tespit edilmiştir. Ayrıca analizci stratejinin finansal ve müşteri boyutlarını pozitif yönde etkilediği görülmüştür. 
Tablo 2: Ölçeklerin DFA Sonuçları

\begin{tabular}{|c|c|c|c|c|c|c|}
\hline MODEL & $\Delta \boldsymbol{X}^{2}$ & sd & $\Delta \boldsymbol{X}^{2 / s d}$ & RMSEA & CFI & GFI \\
\hline $\begin{array}{l}\text { KGÖ Birinci Düzey Çok Faktörlü } \\
\text { Model }\end{array}$ & $93,6^{*}$ & 56 & 1,67 & 0,053 & 0,920 & 0,917 \\
\hline $\begin{array}{l}\text { STÖ Birinci Düzey Çok Faktötlü } \\
\text { Model }\end{array}$ & $137,60 *$ & 64 & 2,15 & 0,049 & 0,97 & 0,96 \\
\hline $\begin{array}{l}\text { FPÖ Birinci Düzey Çok Faktörlü } \\
\text { Model }\end{array}$ & $52,14^{*}$ & 18 & 2,89 & 0,051 & 0,94 & 0,94 \\
\hline
\end{tabular}

RMSEA = RootMeanSquare Error of Approxim ation; CFI = Comparative Fit Index; GFI $=$ Goodness of Fit Index; sd= Serbestlik Derecesi.

Bierwerth ve arkadaşları (2015) tarafindan kurumsal girișimcilik ve örgüt performansı arasındaki etkileşimi ortaya çıkarmak maksadıyla toplamda 13237 firma üzerinde yapılan 43 bağımsız çalışmayı kapsayan bir meta analizi sonucunda stratejik yenilenme, yenilikçilik ve yeni iş girişimi başlatma boyutlarının sübjektif ve objektif örgüt performansını olumlu yönde etkilediği tespit edilmiştir.

Yukarıda sunulan kuramsal gerekçeler 1şı̆̆ında oluşturulan hipotezler aşağıda sunulmuştur.

Hipotez 1: Örgütlerin strateji tiplerinin finansal performansları üzerinde anlamlı bir etkisi vardır.

Hipotez 2: Örgütlerin kurumsal girişimcilik davranışlarının finansal performansları üzerinde anlamlı bir etkisi vardır.

Hipotez 3: Örgütlerin strateji tiplerinin kurumsal girișimcilik davranışları üzerinde anlamlı etkisi vardır.

\section{YÖNTEM}

Araştırmanın evreni ve örneklemi, veri toplama araçları, geçerlilik ve güvenilirlik ile kullanılan istatistikî yöntemler çalışmanın yöntemi bağlamında açıklanmıştır.

\subsection{Evren ve Örneklem}

Araştırmanın evreni Türkiye'de faaliyet gösteren ve elektronik posta adresine ulassılabilen 44530 farklı imalat sanayi firmasıdır. Araştırmanın imalat sanayi firmaları üzerinde yapılmasının nedeni bu firmaların üretimden satışa kadar birçok ölçüt doğrultusunda Türkiye'de üstün performans göstermiş olmalarından kaynaklanmaktadır. Böyle bir yap1 içerisinde örgütlerin başarılı olabilmesi ise uygun stratejilerin oluşturulması ve stratejiye uygun kurumsal girişimcilik davranışlarından geçmektedir. Araştırmanın örneklemi ise evreni temsil edecek nitelikte 44530 üye firmadan rastlantısal olarak seçilen 121 farklı firmadır. Araştırmada, bu firmalarda çalışan ve firma adına cevap veren 121 yöneticiden elektronik anket formu ile toplanan veriler kullanılmıştır. Dolayısıyla araştırmamızın örnekleme yöntemi kolayda örnekleme yöntemidir. Verilerin toplanmasında yöntem olarak anketler belirli zaman aralıkları ile tüm firmalara gönderilmiş, gönderilen elektronik anket formunun 128 adedi geri alınmıştır. Analizler öncesi kayıp veri ve temel değişkenler üzerinden yapılan incelemeler sonucunda, ankette fazla sayida soruyu yanıtlamayan ya da işaretlemeleri alt veya üst değerlerde toplanan 7 yöneticiye ait veriler analizden çıkarılmış, analizlere 121 kişilik bir örneklem üzerinden devam edilmiştir. 0,95 güvenirlik ve 0,10 örneklem hatası ile temsil edilebilecek evren büyüklüklerine göre 96 kișiden oluşan bir örneklemin yaklaşık 50.000 kişilik bir evreni temsil edebileceği belirtilmektedir (Yazıcıŏlu ve Erdoğan, 2004). Buradan hareketle, araştırma örnekleminin $(121>96)$ yeterli olduğu söylenebilmektedir. Araştırmaya katılan firmalar ve sorulara cevap veren yöneticilere ilişkin demografik bilgiler Tablo 1'de sunulmuştur.

Araştırmaya katılan firmalar ve yöneticilere ilişkin tüm oranlar genel olarak dikkate alındığında, örneklemin Türkiye'de faaliyet gösteren imalat sanayi firmalarını dengeli bir şekilde temsil ettiği değerlendirilmektedir.

\subsection{Veri Toplama Araçları}

Araştırmada anket tekniğinden yararlanılmıştır. Bu kapsamda örgütlerin son üç yıl içindeki kurumsal girișimcilik davranışlarını ölçmek üzere Zahra (1996) tarafından kullanılan üç boyutlu 
(yenilikçilik, yeni iş girişimi başlatma ve strateji yenileme) 14 maddelik 5'li Likert tipi Kurumsal Girişimcilik Ölçeği (KGÖ), strateji tiplerinin ölçülmesinde öncü, analizci ve tepkici boyutları Doğan (2008) ile savunmacı boyutu Taşgit (2013) tarafindan kullanılan ve iki ölçeğin birleşiminden oluşan dört boyutlu 19 maddelik 5'li Likert tipi Strateji Tipleri Ölçeği (STÖ) kullanılmıştır. Örgüt performansını ölçmek maksadıyla ise Antoncic ve Hisrich (2001) tarafindan kullanılan iki boyutlu (kârlılık ve büyüme) 6 maddelik 5'li Likert tipi Finansal Performans Ölçeği (FPÖ) kullanılmıştır.

\subsection{Geçerlilik ve Güvenilirlik}

Çalışmamızda ölçeklerin geçerliliği için Doğrulayıcı Faktör Analizi (DFA), güvenilirliği için ise güvenilirlik analizi yapılmıştır. DFA'da dört ayrı model test edilmiştir. Her üç ölçekte de birinci düzey çok faktörlü model diğer tüm modellerden daha yüksek uyum iyiliği göstermiştir. Modelin iyi uyum göstermesi için Ki-kare değerinin anlamlı olmaması beklenmektedir (Meydan \& Şeşen, 2011). Çalışmamızda Ki-kare değerinin anlamlı çıkmasının ise örneklemin büyüklüğünden kaynaklanmış olabileceği düşünülmüştür (Ayyıldız \& Cengiz, 2006). Söz konusu dört değişkenin DFA sonuçları Tablo 2'de sunulmuştur.

KGÖ’nün yapılan güvenilirlik analizi sonucunda boyutlara ilişkin elde edilen güvenilirlik değerleri (Cronbach alfa) sirasiyla 0,$92 ; 0,79$ ve 0,85 toplam için ise 0,93 bulunmuştur. STÖ'nün güvenilirlik değerleri de alt boyutlar için sirasıyla 0,$93 ; 0,78$; 0,78 ve 0,92 ölçeğin toplamı için ise 0,95 olarak hesaplanmıştır. FPÖ'nün güvenilirlik değerleri alt boyutlar için sırasıyla 0,95 ve 0,76 ölçeğin toplamı için ise 0,91 olarak hesaplanmıştır.

\subsection{Kullanılan İstatistiksel Yöntemler}

Veriler, IBM SPSS (21.0) ve AMOS (21.0) programları yardımıyla analize tabi tutulmuştur. Öncelikle tüm değişkenlerin betimleyici istatistikleri kapsamında ortalamaları, standart sapmaları ve puan aralıkları incelenerek boyutlar düzeyinde var olan seviyeler ortaya konulmuştur. Bağımlı ve bağımsız değişkenler arasındaki ilişkileri belirlemek için Pearson korelâsyonu hesaplanmıştır. Bağımsız değişkenlerin bağımlı değişkenler üzerindeki açıklama gücünü bulmak için ise hiyerarşik regresyon analizi uygulanmıştır.

\subsection{Araştırmanın Sınırlılıkları}

Hiç şüphesiz yapılan araştırmanın bazı kısıtlılıkları bulunmaktadır. Bunların başında toplanan verilerin kesitsel olarak tek bir zamanda ve tek bir anket formu ile toplanmasının getirebileceği sınırlamalar sayılabilir. Ayrıca araştırmanın örneklemi Türkiye'de faaliyet gösteren 121 imalat sanayi firmasıdır. Araştırma sonucu elde edilen bulgular, verilerin toplanmasında kullanılan örnekleme göre değişiklik gösterebileceğinden araştırmanın bulguları, verilerin toplandığı 121 imalat sanayi firması ile sınırlıdır. Araştırmada kullanılan

Tablo 3: Deg̈ģkenlere Ait Betimleyici İstatistikler

\begin{tabular}{lccccc}
\hline \multicolumn{1}{c}{ Değişken } & Toplam & Min. & Maks. & Ort. & Ss. \\
\hline Strateji Tịi & & & & & \\
\hline ÖncüStrateji & 121 & 1 & 5 & 4,37 & 0,69 \\
Analizci Strateji & 121 & 1 & 5 & 3,07 & 0,64 \\
Tepkici Strateji & 121 & 1 & 5 & 2,97 & 0,78 \\
Savunm ac1 Strateji & 121 & 1 & 5 & 3,56 & 0,53 \\
\hline Kurumsal Girişimcilik & & & & & \\
\hline Yenilikçilik & 121 & 1 & 5 & 3,34 & 0,99 \\
Yeni İ̧̧Girişimi Başlatm a & 121 & 1 & 5 & 2,68 & 0,63 \\
Stratejik Yenilenme & 121 & 1 & 5 & 3,42 & 0,96 \\
\hline Örgüt Performansı & & & & & \\
\hline Kârlilik & 121 & 1 & 5 & 2,93 & 0,79 \\
Büyüm e & 121 & 1 & 5 & 3,20 & 0,72 \\
\hline
\end{tabular}


ölçekler, örgütlerdeki yöneticilere yöneltilen firmalarına yönelik değerlendirme maddelerinden oluşmaktadır ve bu kapsamda yöneticilerin algısına dayanmaktadır. $\mathrm{Bu}$ nedenle sonuçlar değerlendirilirken tüm değişkenlerin aynı zamanda ve aynı kişiler tarafından cevaplandırıldığı göz önüne alınarak sosyal beğenilirlik etkisi ve ortak yöntem varyansı olabileceği dikkate alınmalıdır.

\section{BULGULAR}

Araştırmada strateji tipleri, kurumsal girişimcilik ve örgüt performansına ait betimleyici istatistikler Tablo 3'te sunulmuştur.

Araştırmada bağımlı ve bağımsız değişkenler arasındaki ilişkileri ortaya çıkarmak amacıyla, hesaplanan Pearson korelâsyon bulguları Tablo 4'te görülmektedir. Korelâsyonlar hesaplanmadan önce yöneticilerin ölçeklerdeki maddelere verdiği puanların ortalamaları alınarak, her örgüt için bir değişken puanı oluşturulmuş ve bu puan değerlendirmeye alınmıştır.

Yapılan korelâsyon analizi sonucunda öncü strateji tipi ile analizci ve savunmacı strateji tipleri arasında aynı yönde ve orta düzeyde, tepkici strateji tipi ile aynı yönlü düşük düzeyde ilişki olduğu görülmüştür. Analizci strateji tipi ile tepkici ve savunmacı strateji tipleri arasında aynı yönlü orta düzeyde ilişki tespit edilmiştir. Strateji tipleri ile kurumsal girişimcilik boyutları arasındaki ilişkilere bakıldığında öncü strateji tipi ile yenilikçilik ve stratejik yenilenme boyutları arasında aynı yönlü ve orta düzeyde, analizci ve tepkici strateji tipleri ile yenilikçilik arasında ters yönlü orta düzeyde, savunmaci strateji tipi ile stratejik yenilenme arasında aynı yönlü ve düşük düzeyde bir ilişki tespit edilmiştir.

Strateji tipleri ile finansal performans arasındaki ilişkilere bakıldığında öncü strateji ile kârlılık arasında aynı yönlü düşük düzeyde, büyüme ile aynı yönlü orta düzeyde bir ilişki tespit edilmiştir. Tepkici strateji tipi ile kârlılık ve büyüme arasında ters yönlü ve düşük düzeyde bir ilişki olduğu görülmüştür. Ayrıca finansal performans boyutlarından kârlılık ile kurumsal girişimciliğin yenilikçilik boyutları arasında anlamlı ve orta düzeyde, stratejik yenilenme boyutu ile aynı yönlü düşük düzeyde bir ilişki tespit edilmiştir. Benzer şekilde finansal performansin büyüme boyutu ile yenilikçilik arasında aynı yönlü ve orta düzeyde, stratejik yenilenme boyutu ile aynı yönlü ve orta düzeyde bir ilişki görülmüştür.

Değişkenler arası doğrudan ilişkileri, bağımsız değişkenlerin bağımlı değişkenler üzerindeki açıklama güçlerini ortaya koymak maksadıyla hiyerarşik regresyon analizi yapılmıştır. Tüm

Tablo 4: Değgşsenler Arasındaki Korelâsyonlar

\begin{tabular}{|c|c|c|c|c|c|c|c|c|c|}
\hline Boyut & (1) & (2) & (3) & (4) & (5) & (6) & (7) & (8) & (9) \\
\hline 1. Oncü Strateji & 1 & & & & & & & & \\
\hline 2. Analizci Strateji & $0,44^{* * *}$ & 1 & & & & & & & \\
\hline 3. Tepkici Strateji & $0,21 *$ & $0,54 * *$ & 1 & & & & & & \\
\hline 4. Savurumac1 Strateji & $0,64^{* * *}$ & $0,57^{* *}$ & $0,72^{* *}$ & 1 & & & & & \\
\hline 5. Yerilikçilik & $0,66^{* *}$ & $-0,40^{* * *}$ & $-0,40^{* * *}$ & 0,02 & 1 & & & & \\
\hline $\begin{array}{l}\text { 6. Yeri Iş Girişimi } \\
\text { Başlatma }\end{array}$ & 0,06 & 0,09 & $-0,10$ & 0,12 & 0,14 & 1 & & & \\
\hline 7. Stratejik Yerilenme & $0,63^{* *}$ & 0,05 & $-0,06$ & $0,20^{*}$ & $0,58 * *$ & $0,22 *$ & 1 & & \\
\hline 8. Kârlullk & $0,19^{* * *}$ & 0,16 & $-0,21^{* * *}$ & 0,09 & $0,39 * *$ & 0,15 & $0,22 *$ & 1 & \\
\hline 9. Büyüme & $0,33^{* *}$ & 0,02 & $-0,29 * *$ & 0,00 & $0,59 * *$ & 0,01 & $0,39 * *$ & $0,62 * *$ & 1 \\
\hline
\end{tabular}


analizlerde demografik değişkenlerin kontrol edilmesi maksadıyla, yöneticilerin örgütteki pozisyonu, cinsiyetleri, çalışma süreleri hiyerarşik regresyonun birinci aşamasında regresyon analizine dâhil edilmiştir. Böylelikle demografik değişkenler kontrol altına alınarak, bağımsız değişkenlerin ayrı ayrı bağımlı değişkenler üzerindeki etkileri ortaya çıkarılmaya çalışılmıştır. Regresyon analizinde öncelikle finansal performans boyutları bağımlı değişken olarak ele alınmış; birinci grupta demografik değişkenler, ikinci grupta kurumsal girişimcilik boyutları, üçüncü grupta strateji boyutları analize dâhil edilmiştir. Müteakiben kurumsal girişimcilik boyutları bağımlı değişken olarak ele alınmış; birinci grupta demografik değişkenler, ikinci grupta strateji boyutları analize dâhil edilmiştir.

Regresyon analizleri yapılmadan önce bağımsız değişkenler arasında çoklu eş doğrusallık olup olmadığı araştırılmıştır (Gürbüz \& Şahin, 2014). Bu maksatla korelâsyon tablosu incelenerek, bağımsız değişkenler arasında korelâsyon katsayılarının 0,80'i geçmediği, değişkenlerin tolerans değerlerinin tümünün $\left(1-\mathrm{R}^{2}\right)$ değerinden büyük olduğu görülmüştür.

Finansal performans boyutlarının açıklanmasında kurumsal girişimcilik ve strateji boyutlarının bağımsız etkilerini gösteren hiyerarşik regresyon analizi bulguları Tablo 5 'te verilmiştir.

Bulgular incelendiğinde kurumsal girişimciliğin yenilikçilik $(\beta=0,532 ; p<0,01)$ ve yeni iş girişimi başlatma $(\beta=0,241 ; p<0,01)$ boyutlarının birlikte kârlılık üzerindeki varyansın \% $\quad 19,6$ 'sının açıklanmasında anlamlı bir etkiye sahip olduğu görülmüştür. Diğer taraftan kurumsal girişimciliğin yenilikçilik boyutunun $(\beta=0,588 ; p<0,01)$ büyüme üzerindeki varyansın \% 36'sının açıklanmasında anlamlı bir etkiye sahip olduğu tespit edilmiştir. Kârlılık üzerindeki varyansın \% 14,8'inn açıklanmasında öncü $(\beta=-0,667 ; p<0,01)$ ve tepkici $(\beta=-0,399 ; p<0,01)$ strateji tiplerinin birlikte anlaml bir etkiye sahip olduğu görülürken, büyüme üzerindeki varyansın \% 4,2'sinin açıklanmasında sadece analizci $(\beta=0,360 ; p<0,01)$ strateji tipinin anlamlı bir etkiye sahip olduğu belirlenmiştir.

Tablo 5'te elde edilen bulgular özetlenecek olursa kurumsal girişimciliğin yenilikçilik ve yeni iş girişimi başlatma davranışlarının kârlılık üzerinde olumlu, strateji tiplerinden öncü ve tepkici strateji tiplerinin ise olumsuz etkisi olduğu görülmüştür. Diğer taraftan kurumsal girişimciliğin yenilikçilik

Tablo 5: Finansal Perform ans B oyutlanın Yordayan Bağgm sı Deg̈gskenlerin Hiyerarģik Regresyon Analizi Bulguları

\begin{tabular}{|c|c|c|c|}
\hline \multirow{2}{*}{ Bağumsıx Değişkenler } & Kârlılık & \multicolumn{2}{|c|}{ Büyüme } \\
\hline & $\Delta \mathbf{R 2}$ & $\beta$ & $\Delta \mathbf{R 2}$ \\
\hline 1. Dem ografik Değgskenler & 0,104 & & 0,304 \\
\hline Örgütteki Pozisyon & 0,151 & $0,434 * *$ & \\
\hline Cinsiyet & 0,007 & 0,047 & \\
\hline Çalışm a Süresi & $-0,217^{*}$ & $-0,179$ & \\
\hline$\Delta F$ & $4,533 * *$ & & \\
\hline 2. Kurum sal Girişim cilik & 0,196 & & 0,361 \\
\hline Yenilikçilik & $0,532 * *$ & $0,588 * *$ & \\
\hline Yeni İ̧̧Giriģimi Başlatma & $0,241 * *$ & 0,106 & \\
\hline Stratejik Yenilentme & $-0,252$ & $-0,002$ & \\
\hline$\Delta \mathrm{F}$ & $10,669 * *$ & & \\
\hline 3.Strateji Tipi & 0,148 & & 0,042 \\
\hline Öncü Strateji & $-0,667^{* *}$ & $-0,230$ & \\
\hline Analizci Strateji & 0,340 & $0,360^{* *}$ & \\
\hline Tepkici Strateji & $-0,399 * *$ & $-0,117$ & \\
\hline Savunm ac1 Strateji & 0,489 & $-0,149$ & \\
\hline$\Delta \mathrm{F}$ & $7,349 * *$ & & \\
\hline
\end{tabular}


davranışlarının büyüme üzerinde olumlu, strateji tiplerinden sadece analizci stratejinin olumlu etkisi olduğu görülmüştür. Tablo 5'te elde edilen hiyerarşik regresyon analiz sonuçları dikkate alındığında 1 ve 2'nci hipotezler değişkenlerin sadece alt boyutları kapsamında etkileşim tespit edildiğinden kısmen desteklenmiştir. Kurumsal girişimcilik boyutlarının açıklanmasında strateji boyutlarının bağımsız etkilerini gösteren hiyerarşik regresyon analizi bulguları Tablo 6'da verilmiştir.

Bulgular incelendiğinde öncü $(\beta=0,579 ; p<0,01)$, tepkici $(\beta=-0,338 ; p<0,01)$ ve savunmaci $(\beta=-0,509$; $\mathrm{p}<0,01) \quad$ strateji tiplerinin birlikte kurumsal girişimciliğin yenilikçilik boyutu üzerindeki varyansın \% 74,4'ünün açıklanmasında anlamlı bir etkiye sahip olduğu görülmüştür. Strateji tiplerinin kurumsal girişimciliğin yeni iş girişimi başlatma boyutu üzerinde ise anlamlı bir etkilerinin olmadığ $(p>0,05)$ tespit edilmiştir. Kurumsal girişimciliğin stratejik yenilenme boyutu üzerindeki varyansın $\%$ 31'inin açıklanmasında ise öncü $(\beta=0,512$; $\mathrm{p}<0,01)$ ve tepkici $(\beta=-0,360 ; \mathrm{p}<0,01)$ strateji tiplerinin birlikte anlamlı bir etkilerinin olduğu belirlenmiştir.

Tablo 6'da elde edilen bulgular özetlenecek olursa kurumsal girişimciliğin yenilikçilik boyutu üzerinde strateji tiplerinden öncü ve tepkici strateji tiplerinin olumsuz etkisi olduğu görülmüştür. Diğer taraftan kurumsal girişimciliğin stratejik yenilenme boyutu üzerinde strateji tiplerinden öncü stratejinin olumlu, tepkici stratejinin ise olumsuz etkisi olduğu görülmüştür. Tablo 6'da elde edilen hiyerarşik regresyon analiz sonuçlarına göre strateji tipleri ile kurumsal girişimcilik değişkenleri arasında sadece bazı alt boyutlar kapsamında etkileşim tespit edildiğinden 3 'üncü hipotez kısmen desteklenmiştir.

\section{TARTIŞMA VE SONUÇ}

Araştırmamız kapsamında verilerinden yararlandığımız 121 imalat sanayi firmasının araştırmanın ana değişkenlerinden biri olan strateji tiplerinin dördünü de son üç yılda ortalamanın üzerinde öncü, savunmaci, analizci ve tepkici strateji tipleri sırasıyla uyguladıkları görülmüştür. Kurumsal girişimcilik davranışları konusunda ise; öncelikle stratejilerini, örgütlerini gözden geçirdikleri ve örgütsel değişime odaklandıkları, ikinci sırada ortalamanın üzerinde yenilikçiliğe ve müteakiben yeni iş girişimi başlatma davranışlarına yöneldikleri tespit edilmiştir. Söz konusu firmalar son üç yılda kârlılık ve büyüme boyutlarında ortalamanın üzerinde performans sergilemişler ancak kârlılıktan ziyade büyümeye yönelmişlerdir.

Örgütlerin strateji tipleri ve kurumsal girişimcilik davranışlarının örgüt performansı üzerindeki açıklama güçlerini ortaya koymak maksadıyla

Tablo 6: Kunum sa1 Girişim cilik Boyutların Yordayan Bağ̀m sı Değģkenlerin Hiyerarşik Regresyon Analizi Bulgular1

\begin{tabular}{|c|c|c|c|c|c|}
\hline \multirow{2}{*}{ Bağumsız Değișkenler } & Yenilikçilik & \multicolumn{2}{|c|}{$\begin{array}{c}\text { Yeni İş Girişimi } \\
\text { Başlatma }\end{array}$} & \multicolumn{2}{|c|}{ Stratejik Yenilenume } \\
\hline & $\Delta \mathbf{R} \mathbf{2}$ & $\beta$ & $\Delta \mathbf{R} \mathbf{2}$ & $\beta$ & $\Delta \mathbf{R} \mathbf{2}$ \\
\hline $\begin{array}{l}\text { 1. Dem ografik } \\
\text { Deg̈jgkenler }\end{array}$ & 0,038 & & 0,144 & & 0,451 \\
\hline Örgütteki Pozisyon & $-0,128 *$ & $-0,431 * *$ & & $0,175 *$ & \\
\hline Cinsiyet & 0,013 & $-0,046$ & & $0,645 * *$ & \\
\hline \multirow[t]{2}{*}{ Çalışm a Süresi } & 0,015 & $-0,139$ & & $0,372 * *$ & \\
\hline & 1,543 & \multicolumn{2}{|c|}{$6,543 * *$} & \multicolumn{2}{|c|}{$31,976 * *$} \\
\hline 2. Strateji Tipi & 0,744 & & 0,031 & & 0,310 \\
\hline Öncü Strateji & $0,579 * *$ & 0,183 & & $0,512 * *$ & \\
\hline Analizci Strateji & 0,177 & 0,123 & & 0,127 & \\
\hline Tepkici Strateji & $-0,338 * *$ & $-0,040$ & & $-0,360 * *$ & \\
\hline Savunm ac1 Strateji & $-0,509 * *$ & $-0,101$ & & $-0,079$ & \\
\hline$\Delta F$ & $96,368 * *$ & 1,06 & & 36 & \\
\hline
\end{tabular}

$* \mathrm{p}<0,05 * * \mathrm{p}<0,01$ 
yapılan hiyerarşik regresyon analizi sonuçları incelendiğinde kurumsal girişimciliğin yenilikçilik ve yeni iş girişimi başlatma davranışlarının kârlılık üzerinde olumlu, strateji tiplerinden öncü ve tepkici strateji tipinin ise olumsuz etkisi olduğu görülmüştür. Kurumsal girişimciliğin stratejik yenilenme boyutu ile analizci ve savunmacı strateji tiplerinin firmaların kârlılık performansı üzerinde bir etkisi olmadığı belirlenmiştir. Firmaların son üç yıldaki büyüme performansı üzerinde kurumsal girişimciliğin sadece yenilikçilik davranışlarının olumlu, strateji tiplerinden sadece analizci stratejinin olumlu etkisi olduğu, diğer üç strateji tipinin bir etkisinin olmadığı görülmüştür. Elde edilen bu bulgular Moreno ve Casillas'1n (2008) bulguları ile uyumludur.

Örgütlerin strateji tiplerinin kurumsal girişimcilik davranışları üzerindeki etkisini tespit etmek maksadıyla yapılan hiyerarşik regresyon analizi sonucunda örgütlerin öncü stratejilerinin kurumsal girişimciliğin yenilikçilik ve stratejik yenilenme boyutlarını olumlu etkilediği görülmüştür. Analizci stratejinin örgütlerin kurumsal girişimcilik davranışları üzerine bir etkisi görülmemiştir. Savunmacı stratejiler kurumsal girişimciliğin yenilikçilik davranışlarını olumsuz etkilemiştir. Tepkici stratejilerin ise kurumsal girişimciliğin yenilikçilik ve stratejik yenilenme davranışlarını olumsuz etkilediği tespit edilmiştir. Yeni iş girişimi başlatma ile strateji tipleri arasında bir etkileşim görülmemiştir.

Öncü strateji örgütlerde yenilikçilik, risk alma ve yeni firsatların takibini sağlamaktadır (Jennings \& Seaman, 1990). Bu nedenle stratejik yenilenmeyi ifade eden iş alanına rekabetçi odaklanma, pazarlama ve dağıtım yöntemlerinde büyük değişiklikler gerçekleştirme, ürün geliştirmeyi yeniden ele alma, süreçleri yeniden düzenlemeyi gerçekleştirmektedirler (Christensen, 2004). Savunmacı ve tepkici stratejiler ise durağanlık ve örgüt içi verimlilik üzerinde odaklanmaktadır. Dolayısıyla, örgütlerin öncü stratejiye odaklanmaları ile yenilikçiliğin ve stratejik yenilenme davranışlarının artması, savunmacı ve tepkici stratejilere odaklanmaları ile azalması yazın ile uyumludur (Zahra \& Garvis, 2000; Moreno \& Casillas, 2008; Akbolat, 2009). Ortalamanın hemen üzerinde bulunan söz konusu firmaların yeni iş girişimi başlatma davranışlarının örgütlerin stratejilerinden ziyade araştırmamız kapsamında olmayan çevre, örgüt yapısı gibi değişkenlerin etkisi ile ortaya çıkmış olabileceği değerlendirilmiştir (Covin \& Slevin, 1991; Zahra, 1993; Zehir \& Eren, 2007).

Sonuç olarak imalat sanayi firmaları üzerinde yapılan araştırmamızda elde edilen bulgular 1şı̆̆ında; kuramsal olarak örgütlerdeki strateji tiplerinin örgütlerin kurumsal girişimcilik davranışları ve örgüt performansı için temel oluşturduğu, strateji tipleri ile kurumsal girişimcilik davranışlarının birbirinin tamamlayıcısı olduğu görülmektedir. Bu kapsamda örgütlerdeki sorumlu yöneticilerin seçecekleri strateji tipiyle uyumlu kurumsal girişimcilik davranışlarına örgütlerini yöneltmeleri olumlu örgüt performansına katk1 sağlayacaktır. Gelecekte yapılacak araştırmalarda örgüt stratejisi ile çevre, örgüt yapısı gibi değişkenlerin birlikte kurumsal girişimcilik davranışları ve örgüt performansı üzerine etkisinin ele alınması önerilmektedir. 


\section{KAYNAKÇA}

Aaboen, L., Lindelöf, P., Koch, C.V. \& Löfsten, H. (2006). Corporate governance and performance of small high-tech firms in Sweden. Technovation, 26, 955-968.

Agarwal, R. \& Helfat, C.E. (2009). Strategic renewal of organizations. Organization Science, 20, 2, 281-293.

Ağca, V. \& Kandemir, T. (2008). Aile işletmelerinde iç girişimcilik finansal performans ilişkisi: Afyonkarahisar'da bir araştırma. Sosyal Bilimler Dergisi, 10, 3.

Akbolat, M. (2009). Türk sağlik sektöründe Miles ve Snow'un stratejik tipolojisi: Hastaneler üzerine bir araştırma. Gazi Üniversitesi İktisadi ve İdari Bilimler Fakültesi Dergisi, 11(3), 127-146.

Akman, G., Özkan, C. \& Eriş, H. (2008). Strateji odaklılık ve firma stratejilerinin firma performansina etkisinin analizi. İstanbul Ticaret Üniversitesi Fen Bilimleri Dergisi, 7(13), 93-115.

Al-Swidi, A.K. \& Fadzil, F.H.B. (2014). The measurements of firm performance's dimensions. Asian Journal of Finance \& Accounting, 6(1), 24-49.

Altuntaş, G. (2010). Girişimcilik ve stratejik yönetim ilişkisi: Bir stratejik girişimcilik modeli ve IMKB Ulusal-100 endeksinde işlem gören işletmeler üzerinde testi (Yayımlanmamış Doktora Tezi). İstanbul Sosyal Bilimler Enstitüsü İşletme Ana Bilim Dalı, İstanbul.

Antoncic, B. \& Hisrich, R.D. (2001). Intrapreneurship: Construct refinement and cross-cultural validation. Journal of Business Venturing, 16, 495-527.

Antoncic, B. \& Hisrich, R.D. (2003). Privatization, corporate entrepreneurship and performance: Testing a normative model. Journal of Developmental Entrepreneurship, 8, 3 .

Antoncic, B. \& Hisrich, R.D. (2004). Corporate entrepreneurship contingencies and organizational wealth creation. Journal of Management Development, 23(6), 518-550.

Antoncic, B. (2006). Impacts of diversification and corporate entrepreneurship strategy making on growth and profitability: A normative model. Journal of Enterprising Culture, 14(1), 49-63.

Antoncic, B. (2007). Intrapreneurship: A comparative structural equation modeling study. Industrial Management \& Data Systems, 107(3), 309-325.

Ayyıldız, H. \& Cengiz, E. (2006). Pazarlama modellerinin testinde kullanılabilecek yapısal eşitlik modeli üzerine kavramsal bir inceleme. Süleyman
Demirel Üniversitesi İktisadi ve İdari Bilimler Dergisi, 11(1), 63-84.

Banker, R.D., Potter, G. \& Srinivasan, D. (2000). An empirical investigation of an incentive plan that includes non-financial performance measures. Account Rev., 75(1), 65-92.

Bierwerth, M., Schwens, C., Isidor, R. \& Kabst, R. (2015). Corporate entrepreneurship and performance: A meta-analysis. Small Business Economics, 45(2), 255-278.

Bloodgood, J.M., Hornsby, J.S., Burkemper, A.C. \& Sarooghi, H. (2015). A system dynamics perspective of corporate entrepreneurship. Small Business Economics, 45, 383-402.

Bouchard, V. (2001). Exploring corporate entrepreneurship: A corporate strategy perspective. European Entrepreneurial Learning, 12, 1-23.

Bracker, J. (1980). The historical development of the stratejik management concept. Academy of Management Review, 5(2), 219-224.

Brinckman J., Grichnik D. \& Kapsa, D. (2010). Should entrepreneurs plan or just storm the castle? A metaanalysis on contextual factors impacting the business planning-performance relationship in small firms. Journal of Business Venturing, 25(1), 24-40.

Bulut, Ç., Fiş, A.M., Aktan, B. \& Yılmaz, S. (2008). Kurumsal girişimcilik: Kavramsal yapı üzerine bir tartışma. Journal of Yaşar University, 3, 1389-1416.

Chakravarhy, B.S. \& Doz, Y. (1992). Strategy process research: Focusing on corporate self-renewal. Strategic Management Journal, 13, 5-14.

Christensen, K.S. (2004). A classification of the corporate entrepreneurship umbrella: Labels and perspectives. International Journal Management Enterprise Development, 1(4), 301-315.

Covin, J.G. \& Slevin, D.P. (1991). A conceptual model of entrepreneurship as firm behavior. Entrepreneurship Theory and Practice, 7-25.

Crawford C. \& Kreiser, P.M. (2015). Corporate entrepreneurship strategy: Extending the integrative framework through the lens of complexity science. Small Business Economics, 45, 403-423.

Dess G.G., Lumpkin, G.T. \& McGee, J.E. (1999). Linking corporate entrepreneurship to strategy, structure and process: Suggested research directions. Entrepreneurship Theory and Practice, 85-102.

Dinçer, M.A.M., Yıldırım, M. \& Dil, E. (2012). Firmanın tercih ettiği stratejinin belirlenmesinde girişimci tipinin etkisi üzerine bir araştırma. Eskişehir Osmangazi IIIBF Dergisi, 7(2), 241-261. 
Doğan, T. (2008). Strateji tipleri ve stratejik yönetim süreçlerinin firma performansina etkileri (Yayımlanmamış doktora tezi). Gebze Teknoloji Enstitüsü Sosyal Bilimler Enstitüsü, İstanbul.

Dollinger, M.J. (2008). Entrepreneurship: Strategies and resources (4. Bask1). Illinois, USA: Marsh Publication

Erkuş, H. (2004). Geleneksel raporlama yöntemlerinin yeni ekonomi karşısındaki durumunun irdelenmesi ve entelektüel sermayenin raporlanması. Süleyman Demirel Üniversitesi İktisadi ve İdari Bilimler Fakültesi Dergisi, 9(2), 303-324.

Fiş, A.M. (2009). Unlocking the relationship between corporate entrepreneurship and performance (Yayımlanmamış doktora tezi). Sabancı Üniversitesi, Istanbul.

Guth, W.D. \& Ginsberg, A. (1990). Guest editors' introduction: Corporate entrepreneurship. Strategic Management Journal, 11, 5-15.

Gürbüz, S. \& Şahin, F. (2014). Sosyal bilimlerde araştırma yöntemleri. Ankara: Seçkin Yayıncılık.

Herrmann, P. (2005). Evolution of strategic management: The need for new dominant designs. International Journal of Management Reviews, 7(2), 111-130.

Hitt, M.A., Ireland, R.D., Camp S.M. \& Sexton, D.L. (2002). Strategic entrepreneurship: Creating a new mindset. Oxford, UK: John Wiley and Sons Ltd.

Hofer, C.W. \& Schendel, D. (1978). Strategy formulation: Analytical concepts. St.Paul., MN: West Publishing Co.

Hornsby, J.S. \& Kuratko, D.F. \& Zahra, S.A. (2002). Middle managers' perception of the internal environment for corporate entrepreneurship: Assessing a measurement scale. Journal of Business Venturing, 17(3), 253-273.

Hornsby, J.S., Kuratko, D.F., Holt, D.T. \& Wales, W.J. (2013). Assessing a measurement of organizational preparedness for corporate entrepreneurship. Journal of Product Innovation Management, 30(5), 937-955.

Ireland R.D., Hitt, M.A., Camp, S.M. \& Sexton, D.L. (2001). Integrating entrepreneurship and strategic management actions to create firm wealth. The Academy of Management Executive (1993-2005). Creating Wealth in Organizations, 15(1), 49-63.

Ireland, R.D., Covin, J.G. \& Kuratko, D.F. (2009). Conceptualizing corporate entrepreneurship strategy. Entrepreneurship Theory and Practice, 19-46.

Isoherranen, V. \& Kess, P. (2011). Analysis of strategy by strategy typology and orientation framework. Modern Economy, 2, 575-583.
Ittner, C.D., Larcker, D.F. (1998). Are non-financial measures leading indicators of financial performance? An analysis of customer satisfaction. Journal of Accounting Research, 36, 1-35.

Jauhari, V. (2005). Corporate entrepreneurship-A framework for competitiveness. Institute for International Management \& Technology. 3rd International Conference on Globalization \& Competitiveness, India.

Jennings, D.F. \& Seaman, S.L. (1990). Aggressiveness of response to new business opportunities following deregulation: An empirical study of established financial firms. Journal of Business Venturing, 5(3), 177-189.

Jennings D.F. \& Hindle, K. (2004). Corporate entrepreneurship and equifinality: An empirical analysis of strategy-structure-performance. Academy of Management Best Conference Paper, 1-8.

Kaplan, R.S. \& Norton, D.P. (1996). The balanced scorecard: Translating strategy into action. Boston: Harvard Business School Press.

Karacaoğlu, K., Bayrakdaroğlu, A. \& San, F.B. (2013). The impact of corporate entrepreneurship on firms' financial performance: Evidence from Istanbul stock exchange firms. International Business Research, 6.

Ketchen, D.J., Thomas, Jr., James B. Jr. \& McDaniel, R.R. (1996). Process, content and context: Synergistic effects on organizational performance. Journal of Management, 22(2), 231-257.

Khani, A. \& Ahmadi, M. (2012). Performance measurement using balanced scorecard measures and strategy based on Miles and Snow's typology in Iran. African Journal of Business Management, 6(46), 11391-11400.

Kraus, S. \& Kauranen, I. (2009). Strategic management and entrepreneurship: Friends or foes?. International Journal of Business Science and Applied Management, 4, 1.

Kuratko, D.F., Hornsby, J.S., \& Hayton, J. (2015). Corporate entrepreneurship: The innovative challenge for a new global economic reality. Small Business Economics, 45, 245-253.

Kurtuldu, A. (2014). Sağlık işletmelerinde kurumsal girişimcilik ve performansa etkisi (Yayımlanmamış doktora tezi). Gazi Üniversitesi Sosyal Bilimler Enstitüsü, Sağlık Kurumları İşletmeciliği Anabilim Dalı, Ankara.

Lekmat, L. \& Chelliah, J. (2011). Surviving the next economic crisis: Corporate entrepreneurship strategies of Thai Automotive SMEs. Journal of International Management Studies, 6(3), 18-35. 
Lumpkin, G.T. \& Dess, G.G. (1996). Clarifying the entrepreneurial orientation construct and linking it to performance. Academy of Management Review, 21(2), 135-172.

Luo, X., Zhou, L. \& Liu, S.S. (2005). Entrepreneurial firms in the context of China's transition economy: An integrative framework and empirical examination. Journal of Business Research, 58, 277-284.

Mainardes, E., Ferreira J. \& Raposo, M. (2014). Strategy and strategic management concepts: Are they recognised by management students? $E \& M$ Ekonomie and Management, 17(1), 43-61.

Martins, T.S. \& Kato, H.T. (2010). An analytical framework for Miles and Snow typology and dynamic capabilities. Encontro da Anpad, 1-14.

Meydan C.H. \& Basım, H.N. (2007). Kurumsal YönetimŞirket Performansı İlişkisi: Kuramsal Bir Analiz. Kara Harp Okulu Savunma Bilimleri Dergisi, 6(2), 48-67.

Meydan, C.H. \& Şeşen, H. (2011) Yapısal eşitlik modellemesi uygulamaları. Ankara: Detay Yayıncılık.

Meyer, G.D. \& Heppard, K.A. (2000). Entrepreneurship as strategy: Competing on the entrepreneurial egde. Thousand Oaks, CA: Sage Publications.

Miles, R.E. \& Snow, C.C. (1978). Organizational strategy structure and process. New York: Mcgraw Hill.

Moreno, A.M. \& Casillas, J.C. (2008). Entrepreneurial orientation and growth of SMEs: A causal model. Entrepreneurship Theory and Practice, 32(3), 507528.

Morris, M.H., Kuratko, D.H. \& Jeffrey, G.C. (2011). Corporate entrepreneurship \& Innovation. Cengage Learning.

Ocak, M. \& Basım, H.N. (2015). Kurumsal Girişimciliğin Örgüt Performansı ile Etkileşimi. Turgut Özal Uluslararası Ekonomi ve Siyaset Kongresi-III (11-13 Haziran), Malatya, 8-23.

Ogot, M.M. (2012). A generic competitive business strategies typology for micro-enterprises. European Journal of Business and Management, 4(20), 98-110.

Özdemirci, A. (2011). Corporate entrepreneurship and strategy process: A performance based research on Istanbul Market. Procedia Social and Behavioral Sciences, 24, 611-626.

Peltola, S. (2012). Can an old firm learn new tricks? A corporate entrepreneurship approach to organizational renewal. Business Horizons, 55, 43-51.

Raman, A. (2015). Corporate entrepreneurship: A strategic and structural perspective. International
Journal of Business and Administration Research Review, 2(9), 131-133.

Ronda-Pupo, G.A., \& Guerras-Martín, L.Á. (2010). Dynamics of the scientific community network within the strategic management field through the Strategic Management Journal 1980-2009: the role of cooperation. Scientometrics, 85(3), 821-848.

Rodrigues, S.C.S.F. (2002). Business strategy and organizational performance: An analysis of the Portuguese Mould Industry (Yayımlanmamış doktora tezi). University of Wolverhampton.

Rutherfold, M.W. \& Holt, D.T. (2004). Corporate entrepreneurship: An empirical look at the innovatiness dimension and its antecedents. Journal of Organizational Change Management, 20(3), 429446.

Sânchez, A.M., Criado, M.O.U \& Martinez, A.M.R. (2009). The decision to use alliances as corporate entrepreneurship: The role of resources and skills. Group Decision Negotiation, 18, 431-448.

Sarvan, F., Arıcı, E.D., Özen, J., Özdemir, B. \& İçigen, E.T. (2003). On stratejik yönetim okulu: Biçimleşme okulunun bütünleştirici çerçevesi. Akdeniz İ.̇.B.F. Dergisi, 6, 73-122.

Sebora, T.C., Theerapatvong, T. \& Lee, S.M. (2010). Corporate entrepreneurship in the face of changing competition. A case analysis of six Thai manufacturing firms. Journal of Organizational Change Management, 23(4), 453-470.

Sihvonen, A. (2010). Success strategies in declining industries-A case survey (Yayımlanmamış yüksek lisans tezi). AALTO University School of Economics Department of Marketing and Management.

Steiner, G. \& Miner, J. (1977). Management policy and strategy: Text, readings and cases. New York: Macmillan.

Sueyoshi, T., Goto, M. \& Omi, Y. (2010). Corporate governance and firm performance: Evidence from Japanese manufacturing industries after the lost decade. European Journal of Operational Research, 203, 724-736.

Summer, C.E. (1980). Strategic behavior in business and government. Boston: Little Brown.

Şanal, M. (2011). Aile işletmelerinde kurumsallaşma ve kurumsal girişimcilik üzerine bir araştırma (Yayımlanmamış doktora tezi). Çukurova Üniversitesi, Sosyal Bilimler Enstitüsü, Adana.

Taşgit, Y.E. (2013). İş çevresi, kurum kültürü ve işletme stratejileri arasındaki ilişkiler: Otel işletmeleri üzerinde bir araştırma (Yayımlanmamış doktora 
tezi). Gebze Yüksek Teknoloji Enstitüsü Sosyal Bilimler Enstitüsü, İstanbul.

Theresa, L., Chan, K.F., Susan, H.C., Tai, H.C. \& David, K.C. (2010). Corporate entrepreneurship of IJVs in China. Management Research Review, 33(1), 6-22.

Ülgen, H. \& Mirze, K. (2004). Işsletmelerde stratejik yönetim. İstanbul: Literatür Yayıncılık.

Üstün, F. (2015). Örgütlerde sıkllı-esneklik boyutunun örgütsel güven, kurumsal girişimcilik ve firma performansina etkisi: Türkiye'nin öncü sanayi işletmeleri üzerine bir araştırma (Yayımlanmamış doktora tezi). Çukurova Üniversitesi, Sosyal Bilimler Enstitüsü İşletme Anabilim Dalı, Adana.

Wang, C. (2008). Entrepreneurial orientation, learning orientation and firm performance. Entrepreneurship Theory and Practice, 32(4), 635-656.

Yazıcıŏlu, Y. \& Erdoğan, S. (2004). Spss uygulamalı bilimsel araştırma yöntemleri. Ankara: Detay Yayınc1lı.

Zahra, S.A. (1993). Environment, corporate entrepreneurship and financial performance: A taxonomic approach. Journal of Business Venturing, $8,319-340$

Zahra, S.A. (1996). Governance, ownership, and corporate entrepreneurship: The moderating impact of industry technological opportunies. Academy of Management Journal, 39(6), 1713-1735.

Zahra, S.A. \& Garvis, D.M. (2000). International corporate entrepreneurship and firm performance: The moderating effect of international environmental hostility. Journal of Businness Venturing, 15, 469492.

Zahra, S.A., Neubaum, D.O. \& Morten, H. (2000). Entrepreneurship in medium-size companies: Exploring the effects of ownership and governance systems. Journal of Management, 26(5), 947-976.

Zahra, S.A., Randersonk, K. \& Fayolle, A. (2013). Corporate entrepreneurship: Where are we? Where can we go from here?M@n@gement, 16(4),357-432.

Zehir, C. \& Eren, M.Ş. (2007). Örgütsel faktörlerin kurumsal girişimcilik ve iş performansı üzerine etkileri: Türk otomotiv sektörü üzerine bir alan araştırması. Journal of American Academy of Business, 10, 2. 